Pesq. Vet. Bras. 38(1):133-136, janeiro 2018

DOI: $10.1590 / \mathrm{S} 0100-736 \mathrm{X} 2018000100021$

\title{
Colloid osmotic pressure during and after surgical interventions in adult and geriatric $\operatorname{dog} \mathbf{s}^{1}$
}

\author{
Mario A.F. Rego ${ }^{2 *}$, Andreza Conti-Patara ${ }^{3}$, Haley S. de Carvalho ${ }^{4}$ \\ and Silvia R.G. Cortopassi ${ }^{2}$
}

\begin{abstract}
Rego M.A.F., Conti-Patara A., Carvalho H.S. \& Cortopassi S.R.G. 2018. Colloid osmotic pressure during and after surgical interventions in adult and geriatric dogs. Pesquisa Veterinária Brasileira 38(1):133-136. Faculdade de Medicina Veterinária e Zootecnia, Universidade de São Paulo, Av. Prof. Dr. Orlando de Marques Paiva 87, Cidade Universitária, São Paulo, SP 05508-270, Brazil. E-mail: maferraro@usp.br

The objective this study is to evaluate colloid osmotic pressure (COP) fluctuations in adult and senile dogs during surgical interventions. Thirty-six healthy dogs to surgical interventions, distributed in two groups, A and B, according to their age, and were all subjected to the same anesthetic protocol. Values of albumin, total plasmatic protein and COP were evaluated from samples collected before pre-anesthetic medication, fifteen minutes after pre-anesthetic medication, and shortly after the end of the intervention. Results were tested using t-test to compare among groups and ANOVA for repeated measures followed by Tukey's test to compare different moments within the same group. Statistical significance was set at $\mathrm{p}<0.05$. In both groups, significant decreases were observed in colloid osmotic pressure, as well as albumin and total proteins $(\mathrm{p}<0.001)$. Despite slightly lower COP values for the group of adult animals, this difference was not significant as there was a high individual variation within groups. The results therefore indicate no difference in colloid osmotic pressure values or fluctuation patterns among adult and senile dogs $(p=0.124)$. The observed results indicate that colloid osmotic pressure decreases significantly during surgical procedures, due to hypotension caused by the anesthetic drugs and to hemodilution caused by the fluid administration but there is no difference between groups. However, in both adult and senile dogs, these variables recover gradually after the animals awaken, through increased urine production and recovery of vascular tonus, indicating the successful reestablishment of homeostasis.
\end{abstract}

INDEX TERMS: Colloid osmotic pressure, dogs, total protein, anesthesia.

RESUMO.- [Pressão coloidosmótica durante e depois de intervenção cirúrgica em cães adultos e geriátricos.] 0 objetivo deste estudo é avaliar as flutuações da pressão coloidosmótica (PCO) em cães adultos e idosos durante a intervenção cirúrgica. Foram utilizados 36 cães hígidos

\footnotetext{
${ }^{1}$ Received on June 26, 2016.

Accepted for publication on May 23, 2017.

${ }^{2}$ Departamento de Cirurgia, Faculdade de Medicina Veterinária e Zootecnia (FMVZ), Universidade de São Paulo (USP), Av. Prof. Dr. Orlando de Marques Paiva 87, Cidade Universitária, São Paulo, SP 05508-270, Brazil.

*Corresponding author: maferraro@usp.br

${ }^{3}$ Vet Support Terapia Intensiva Veterinária, Av. Iraí 852, Moema, São Paulo, SP 04082-002, Brazil.

${ }^{4}$ Escritório de Desenvolvimento Rural de Pindamonhangaba, Coordenadoria de Assistência Técnica Integral (CATI), Av. Nossa Senhora do Bom Sucesso 1.181, Campo Alegre, Pindamonhangaba, SP 12420-010, Brazil.
}

submetidos à intervenção cirúrgica, distribuídos em dois grupos de acordo com a idade e submetidos ao mesmo protocolo anestésico. Os valores de albumina, proteína plasmática total e PCO foram avaliados de amostras coletadas antes da medicação pré-anestésica, 15 minutos após e ao final do procedimento cirúrgico. Os dados obtidos foram analisados através do teste-t para comparação entre os grupos e ANOVA para medidas repetidas seguido do teste de Tukey para comparar diferentes momentos dentro do mesmo grupo. Foram considerados estastisticamente diferentes com $\mathrm{p}<0.05$. Em ambos os grupos foram observados decréscimo dos valores da pressão coloidosmótica, como os valores de albumina e proteína total $(\mathrm{p}<0.001)$. Apesar de ligeiramente inferior, os valores de PCO para o grupo adulto não apresentaram diferença significativa. Os resultados indicam que não houve diferença nos valores da 
pressão oncótica ou padrão de flutuação entre adultos e idosos $(\mathrm{p}=0,124)$. Os resultados observados indicam significativo decréscimo da pressão coloidosmótica durante os procedimentos cirúrgicos devido à hipotensão causada pelos fármacos anestésicos e pela hemodiluição causada pela administração de fluídos, mas não houve diferença entre os grupos. Entretanto, tanto em cães adultos como idosos, essas variações retornaram gradualmente após a recuperação dos animals, através do aumento da produção de urina e da recuperação do tônus vascular, indicando restabelecimento da homeostase.

TERMOS DE INDEXAÇÃO: Pressão coloidomótica, cães, proteína total, anestesia.

\section{INTRODUCTION}

Plasma oncotic or colloid osmotic pressure (COP) is the force or osmotic pressure exerted by macromolecules, such as albumin, in the intravascular compartment. These macromolecules, with a molecular weight high enough to limit their permeability through the vascular endothelium, are largely responsible for the maintenance of water within the blood vessels (Howland et al. 1976, Wellman et al. 2006). Changes in the concentrations of these macromolecules will alter liquid exchanges, hampering cell nutrition and oxygenation.

Hypo-oncotic states may occur secondarily to changes in endothelial integrity, protein loss, dilution or decreased production of protein, or increases in vascular permeability with leakage of plasmatic protein to the interstitium. Loss of colloids leads to a concurrent loss of plasma, reducing circulatory volume and perfusion (Magdesian 2002), and thus contributing to an increased risk of pulmonary edema, hypoxemia and mortality (Weil et al. 1979).

Normal values of plasma oncotic pressure in animals range from 21 to $25 \mathrm{mmHg}$, and values below $14 \mathrm{mmHg}$ increase the risk of edema (Rudloff \& Kirby 2000). The COP may be calculated directly from the concentrations of total proteins or albumin and globulins through cubic functions (Haskins 2001). Measurements of COP have been used to guide IV administration of crystalloid and synthetic colloid fluids, can be used to assess the risk of edema formation (Haynes et al. 1989, King 2000, Rudloff \& Kirby 2000, Wellman et al. 2006). Therefore, knowledge of decrease in COP due to general anesthesia in dogs may help guide perioperative management.

Several studies have examined the interference of anesthetic drugs and the administration of fluids on the COP (Weil et al. 1979, Moore \& Garvey 1996, Sano et al. 2005, Wright \& Hopkins 2008); however, no studies have yet addressed the differences among adult and geriatric dogs. The purpose of this study was to evaluate how COP may be affected in dogs of different age classes during the anesthetic period.

\section{MATERIALS AND METHODS}

Thirty-six dogs, healthy or with mild systemic disease (ASA risk category I or II), were admitted by the Surgery Service, the Veterinary Hospital of the Faculty of Veterinary Medicine, University of São Paulo. The study was assessed and approved by the Bioethics
Committee of our institution, and the animals were included after the owner's consent. The animals were evenly distributed in two groups according to the age class criteria proposed by Goldston (1989): Group A (adult dogs) with ages from 2 to 7 years and Group B (geriatric dogs) with ages greater than 8 years.

Animals were subjected to surgical interventions with a duration of fewer than two hours. General anesthesia followed protocols proposed by the Anesthesia Service of the institution. Tranquilization was performed using intramuscular administration of acepromazine at $0.05 \mathrm{mg} / \mathrm{kg}$ (Acepran 0,2\%, Vetnil, São Paulo/SP, Brazil) and opioid drugs: meperidine at $3 \mathrm{mg} / \mathrm{kg}$ (Dolosal 50mg/ $\mathrm{mL}$, Cristália, São Paulo/SP, Brazil) or tramadol at 2mg/kg (Tramadon 50mg/mL, Cristália, São Paulo/SP, Brazil). Induction was achieved through intravenous administration of propofol at a dosage of 5mg/kg (Propovan 10mg/mL, Cristália, São Paulo/SP, Brazil), and anesthesia was maintained through isofluorane (Isoforine, Cristália, São Paulo/SP, Brazil) inhalation in 100\% oxygen.

Replacement and maintenance fluid therapy with crystalloid solutions ( $0.9 \%$ saline or Lactated Ringer's solution) were administered throughout the procedure; however, administration was not standardized, and the infused volume was adjusted according to blood pressure. If the systolic arterial pressure (SAP) was $<90$ $\mathrm{mmHg}$, the animal received a bolus of up to $10 \mathrm{~mL} / \mathrm{kg}$.

The following parameters were measured before, during and after anesthesia: heart rate (HR), heart rhythm, respiratory rate (RR - observation of thoracic movements), non-invasive systolic, diastolic and mean arterial pressures with a multiparametric monitor (DX2021; Dixtal ${ }^{\circledR}$, São Paulo/SP, Brazil), and rectal body temperature $\left(\mathrm{T}^{\circ} \mathrm{C}=\right.$ maximum temperature thermometer $)$.

Blood samples were collected through the cephalic vein prior to pre-anesthetic medication (M0), fifteen minutes after pre-anesthesia (M1), and shortly after the end of the surgical intervention (M2). Blood sampling was not performed on the same vein used for fluid administration. Each sample was centrifuged (ExcelsaBaby I 206, Fanem ${ }^{\circledR}$, São Paulo/SP, Brazil) at 5000 rpm for 5 minutes, serum was extracted and measurements of albumin (Albumin kits, Wiener Lab ${ }^{\circledR}$, São Paulo/SP, Brazil), total plasmatic protein and colloid osmotic pressure (Colloid Osmometer Wescor $4420^{\circledR}$, Wescor Inc., Miami, USA) were conducted.

Colloid osmotic pressure was measured in $0.325 \mathrm{~mL}$ of each serum sample. Samples were injected into the test chamber, which was separated from the reference chamber by a semi-permeable membrane. The reference chamber was filled with saline solution and mimicked the Gibbs-Donnan effect of the interstitial tissue. Water migrated from the reference chamber to the test chamber under the influence of osmolarity, producing a pressure gradient in the reference chamber. After equilibrium, the negative pressure gradient was measured by the sensory diaphragm. As pressure changed, the diaphragm modulated the electrical impedance and amplified signal potency, which was then converted into $\mathrm{mmHg}$ measurements by a microprocessor (Rudloff \& Kirby 2000).

Statistics. Results for each parameter were tested among groups using t-test and ANOVA for repeated measures followed by Tukey's test to compare different moments in the same group. Comparisons with $\mathrm{p}<0.05$ were considered significant.

\section{RESULTS}

A total of 36 animals were examined, distributed in two groups according to their age classes, Group A and Group $B$. The body mass was not significantly different among groups (Group A $=27 \pm 9.05 \mathrm{~kg}$, Group B $=26 \pm 11.43 \mathrm{~kg}$ ). The mean age of the examined dogs was $4.2 \pm 2$ years in Group A and 10.4 \pm 2 years in Group B. The procedure du- 
Table 1. Comparison of COP, total protein and albumin between groups (Mean \pm SD)

\begin{tabular}{lcccc}
\hline & & M0 & M1 & M2 \\
\hline COP & Group A & $23,5 \pm 5^{*}$ & $20,5 \pm 4$ & $16,4 \pm 4^{*}$ \\
(mmHg) & Group B & $24 \pm 3$ & $23 \pm 3$ & $18 \pm 4$ \\
Total protein & Group A & $6,8 \pm 0,7^{*}$ & $6,5 \pm 0,5$ & $5,4 \pm 0,7^{*}$ \\
(g/dL) & Group B & $6,7 \pm 0,5$ & $6,5 \pm 0,4$ & $5,5 \pm 0,4$ \\
Albumin & Group A & $3,4 \pm 0,4^{*}$ & $3,5 \pm 0,4$ & $2,9 \pm 0,4^{*}$ \\
(g/dL) & Group B & $3,4 \pm 0,5$ & $3,5 \pm 0,5$ & $2,8 \pm 0,6$
\end{tabular}

p<0.05 M0 different of M2.

ration was not different among groups (Group A $=57 \pm 29$ min, Group B $=59 \pm 33 \mathrm{~min}$ ). The values of fluid therapy were $4.4 \pm 0.9 \mathrm{ml} / \mathrm{kg} / \mathrm{h}$ (replacement) and $15.6 \pm 4.9 \mathrm{ml} / \mathrm{kg} / \mathrm{h}$ (maintenance) for Group A and $4.4 \pm 0.9 \mathrm{ml} / \mathrm{kg} / \mathrm{h}$ (replacement) and $15.4 \pm 4.4 \mathrm{ml} / \mathrm{kg} / \mathrm{h}$ (maintenance) for Group B.

The results of COP, total protein and albumin are presented in Table 1. A decrease in COP, total protein and albumin was noted among sampling intervals $(\mathrm{p}<0.001)$; however, no significant differences were found between groups $(\mathrm{p}=0.124)$.

In this study, there were no significant differences in the COP between Groups A and B. Despite slightly lower COP values for the group of adult animals, this difference was not significant, as there was a high individual variation within groups. The results therefore indicate no difference in colloid osmotic pressure values or fluctuation patterns among adult and geriatric dogs.

\section{DISCUSSION}

General anesthesia is responsible for changes in cardiac output and vascular resistance, and the latest research has shown changes in colloid osmotic pressure associated with anesthetic drugs and fluids infusion (Boscan \& Steffey 2007, Boscan et al. 2007, Wright \& Hopkins 2008, Dismukes et al. 2010, Raftery et al. 2016). As hydrostatic forces change, intravascular fluid may move freely, passing from the interstitium to the intravascular compartment and vice-versa (Nielsen \& Engell 1985). Wright \& Hopkins (2008) compared groups of dogs that either received or did not receive replacement fluids, and they observed that colloid osmotic pressure and total plasmatic protein (TPP) after the end of the surgical procedure were higher in animals that did not receive fluids. The authors also concluded that fluctuations in COP may occur even in the absence of fluid replacement, revealing the interference of fluid administration on COP and TTP during surgical procedures. Raftery et al. (2016) observed horses undergoing orthopedic surgery placed on intravenous fluids had an increase in post-operatively COP. Because of this, in this study it was unnecessary to evaluate COP and TTP after recovery from the surgical procedure, and we examined only the differences in those parameters between the groups during the trans-operatory period. Colloid osmotic pressure, like TP, decreased greatly over the course of crystalloid fluid infusion during anesthesia for laparotomy in horses with colic. This change may predispose the animal to tissue edema with subsequent morbidity (Boscan \& Steffey 2007).

COP in healthy dogs may decrease by $5 \mathrm{mmHg}$ on avera- ge after general anesthesia and that this decrease may not be reliably predicted by the volume of fluids administered IV during anesthesia (Dismukes et al. 2010). In human patients, a study has demonstrated that increases in blood volume through fluid administration reduce total plasmatic protein as well as colloid osmotic pressure (Sano et al. 2005). In that study, the decrease in colloid osmotic pressure was associated with the arterial hypotension promoted by the anesthetic drugs and fluid administration. Arterial pressure reduction and vasodilatation promote fluid influx from the interstitium into the vessels, reducing COP and increasing blood volume. Because of that, any blood loss during surgery would cause the same effect on COP, and at the same time there would be a direct loss of albumin and other proteins.

Before the administration of pre-anesthetic drugs, adult and senile animals presented colloid osmotic pressures of $23 \pm 5$ and $24 \pm 3 \mathrm{mmHg}$, respectively, and thus were within normal values (21-25 $\mathrm{mmHg}$ ) (Bisera et al. 2008).

The albumin and total protein values also decreased from M0 to M2 (Group A = 8\% and 10\% respectively, Group $\mathrm{B}=7 \%$ and $8 \%$ respectively). Despite differences between different sampling timepoints within groups, there were no differences between groups at these timepoints $(p=0.124)$. The albumin and total protein decreases, unlike the COP decrease, occur almost entirely due to the hemodilution caused by fluid administration, in association with trans-operatory blood loss. These decreases do not result from anesthetic drug effects, as most of those drugs are bound to albumin (for example, propofol circulates 96 to $98 \%$ bound to plasma protein). Not only fluid maintenance, but also fluid replacement, contribute considerably to the decreases in those parameters. Boscan et al. (2007) described colloid osmotic pressure and total protein concentration decreased in horses during general anesthesia for elective surgical procedures. In that study, the COP and TP decreased from $22.2 \pm 2 \mathrm{mmHg}$ and $6.9 \pm 0.4 \mathrm{gdL}$ before anesthesia, to $15 \pm 1.3 \mathrm{mmHg}$ and $5.1 \pm 0.2 \mathrm{gdL}$ respectively, when crystalloids were.

Similarly, several drugs cause vasodilatation and reduce cardiac output, reducing capillary hydrostatic pressure. Pre-anesthetic medication with acepromazine and opioids (such as meperidine or tramadol, which were used in this study) may cause significant vasodilatation by antagonism of alpha 1 receptors and possibly a small liberation of histamine (Adams 2001, Hardman et al. 2001). Both propofol and isofluorane reduce arterial pressure and systemic vascular resistance (Kelly \& Steffey 1981). These two effects may potentiate a late reduction of capillary hydrostatic pressure, favoring an additional fluid influx into the blood vessels. Furthermore, isofluorane can increase the permeability of the alveolocapillary barrier (Kandatsu et al. 2005) and also affect capillaries in other organs of the body (Brekke et al. 2013). That could contribute to vasodilation and an increase in vascular permeability (Murohara et al. 1998). These effects, combined with blood loss during the procedure, result in a second large decrease in COP at the end of surgery (Sano et al. 2005) before it is reestablished to normal values. 
Because this was a clinical study, some variables could have interfered with the data evaluation. Despite being healthy animals, they underwent different surgical procedures, and the occurrence and treatment of hypotension can interfere with the COP values. Vasoactive drugs were not used in this study, and the hypotension was treated with fluid therapy, which directly affects the COP. Another limitation of this study was not evaluating the COP after the procedure until it returned to baseline. However, the anesthetic protocol used in both groups had minimal variation, which reduces the anesthetic interference in the data analysis. These data are important to understand how COP develops during the surgical procedure in healthy adults and elderly patients to guide treatment in ill animals.

The loss of colloids leads to a concurrent loss of plasma, which reduces circulatory volume and perfusion and thus contributes to an increased risk of pulmonary edema and organ dysfunctions. Therefore, measuring COP provides vital information for the management of clinical and surgical cases.

\section{CONCLUSIONS}

Blood loss during surgery and the increase in blood volume due to fluid administration, leading to hemodilution, reduce the concentration of total plasmatic protein, particularly albumin, as well as colloid osmotic pressure.

This decrease is also associated with arterial hypotension and diminished vascular resistance from the effect of anesthetic drugs.

The decreases in COP, TPP and albumin occurred similarly in adult and geriatric dogs.

The observed results indicate that colloid osmotic pressure decreases significantly during surgical procedures, due to hypotension caused by the anesthetic drugs and to hemodilution caused by fluid administration, but there was no difference between the groups.

In adult and geriatric dogs, these variables recover gradually after the animals awaken, through increased urine production and recovery of vascular tonus, indicating the successful reestablishment of homeostasis.

\section{REFERENCES}

Adams H.R. 2001. Veterinary Pharmacology and Therapeutics. 8th ed. Iowa State University Press, Ames, p.268-342.

Bisera J., Weil M.H. \& Michaels S. 2008. An "osmometer" for clinical measurement of colloid osmotic pressure of plasma. Clin. Chem. 24:15861589.

Boscan P. \& Steffey E.P. 2007. Plasma colloid osmotic pressure and total protein in horses during colic surgery. Vet. Anaesth. Analg. 34:408-415.

Boscan P., Watson Z. \& Steffey E.P. 2007. Plasma colloid osmotic pressure and total protein trends in horses during anesthesia. Vet. Anaesth. Analg. 34:275-283.
Brekke H.K., Hammersborg S.M., Lundemoen S., Mongstad A., Kvalheim V.L., Haugen O. \& Paul Husby P. 2013. Isoflurane in contrast to propofol promotes fluid extravasation during cardiopulmonary bypass in pigs. Anesthesiology 119:861-870.

Dismukes D., Thomovsky E.J., Mann F.A. \& Middleton J.R. 2010. Effects of general anesthesia on plasma colloid oncotic pressure in dogs. J. Am. Vet. Med. Assoc. 236:309-311.

Goldston R.T. 1989. Geriatrics and gerontology. Vet. Clin. N. Am. 19:1-202.

Hardman J.G., Limbird L.E. \& Gilman A.G. 2001. Goodman \& Gillman's The Pharmacological Basis of Therapeutics, 10th ed. McGraw-Hill, New York.

Haskins S.C. 2001. Equilíbrio hidroeletrolítico e ácido-base: manutenção no período perioperatório, p.288-307. In: Paddleford R.R. (Ed.), Manual de Anestesia em Pequenos Animais. $2^{\underline{a}}$ ed. Roca, São Paulo.

Haynes G.R., Conroy J.M. \& Baker D.J. 1989. Colloid oncotic pressure as a guide for the anaesthesiologist in directing fluid therapy. South Med. J. 82:618-623.

Howland W.S., Schweizer O. \& Ragasa J. 1976. Colloid oncotic pressure and levels of albumin and total protein during major surgical procedures. Surg. Gynecol. Obstet. 143:592-596.

Kandatsu N., Nan Y.S., Feng G.G., Nishiwaki K., Hirokawa M., Ishikawa K., Komatsu T., Yokochi T., Shimada Y. \& Ishikawa N. 2005. Opposing effects of isoflurane and sevoflurane on neuro- genic pulmonary edema development in an animal model. Anesthesiology 102:1182-1189.

Kelly A.B. \& Steffey E.P. 1981. Inhalation anesthesia: drugs and techniques. Vet. Clin. N. Am., Large Anim. Pract. 3:59-71.

King L.G. 2000. Colloid osmometry, p.116-118. In: Bonagura J.D. (Ed.), Kirk's Current Veterinary Therapy. Vol.XIII. Small Animal Practice. W.B. Saunders, Philadelphia.

Magdesian K.G. 2002. Monitoring techniques. Am. Coll. Vet. Intern. Med. Forum, 20th ACVIM, Dallas, TX, p.180-182.

Moore L.E. \& Garvey M.S. 1996. The effect of hetastarch on serum colloid osmotic pressure in hypoalbuminemic dogs. J. Vet. Intern. Med. 10:300303.

Murohara T., Horowitz J.R., Silver M., Tsurumi Y., Chen D., Sullivan A. \& Isner J.M. 1998. Vascular endothelial growth factor/vascular permeability factor enhances vascular permeability via nitric oxide and prostacyclin. Circulation 97:99-107.

Nielsen O.M. \& Engell H.C. 1985. The importance of plasma colloid osmotic pressure for interstitial fluid volume and fluid balance after elective abdominal vascular surgery. Ann. Surg. 203:25-29.

Raftery A.G., Morgan R.A. \& MacFarlane P.D. 2016. Perioperative trends in plasma colloid osmotic pressure in horses undergoing surgery. J. Vet. Emerg. Crit. Care 26(1):93-100.

Rudloff E. \& Kirby R. 2000. Colloid osmometry. Clin. Tech. Small Anim. Pract. 15(3):119-125.

Sano Y., Sakamoto A., Oi Y. \& Ogawa R. 2005. Anesthesia and circulation blood volume. Eur. J. Anesthesiol. 22:258-262.

Weil M.H., Henning R.J. \& Puri V.K. 1979. Colloid osmotic pressure: clinical significance. Crit. Care Med. 7:113-116.

Wellman M.L., DiBartola S.P. \& Kohn C.W. 2006. Applied physiology of body fluids in dogs and cats, p.3-26. In: DiBartola S.P. (Ed.), Fluid, Electrolyte, and Acid-Base Disorders in Small Animal Practice. 3rd ed. Saunders Elsevier, St Louis.

Wright B.D. \&Hopkins A. 2008. Changes in colloid osmotic pressure as a function of anesthesia and surgery in the presence and absence of isotonic fluid administration in dogs. Vet. Anaesth. Analg. 35:282-288. 